\title{
Analisis Perbedaan Faktor Enabling Praktik Buang Air Besar Desa ODF dan Belum ODF Kota Surabaya
}

\section{Analysis of the Differences of Enabling Factors in Large Water Waste Practices In ODF and Not yet ODF Village Surabaya City}

\author{
Santy Margaritha Dasi* ${ }^{1}$, Putri Nabilah Ramadhani ${ }^{1}$
}

\begin{abstract}
ABSTRAK
Latar Belakang: Upaya peningkatan derajat kesehatan pada sektor lingkungan salah satunya dengan pengadaan sarana lingkungan fisik yang sehat seperti jamban keluarga. Berdasarkan data Laporan Kemajuan Akses Sanitasi Kumulatif Nasional Tahun 2019, penduduk Jawa Timur yang masih menumpang ke jamban sehat sebanyak 879.969 Kepala Keluarga dan yang berperilaku Open Defecation (OD) sebanyak 969.663 KK.

Tujuan: Menganalisis perbedaan faktor enabling terhadap praktik buang air besar antara desa belum ODF dengan desa ODF.

Metode: Jenis penelitian observasional analitik kuantitatif dan kualitatif dengan desain penelitian Cross Sectional. Dianalisis secara univariate menggunakan uji One Sample Kolmogorov-Smirnov test dan bivariat menggunakan uji Mann-Whitney U test. Dari uji ini diperoleh kemungkinan hasil uji yaitu signifikan atau bermakna $\alpha=0,05$ maka terdapat perbedaan yang bermakna antara variable yang diuji. Hipotesa diterima apabila p-value $\leq 0,05$.

Hasil: Uji statistik Mann Whitney U test menyatakan adanya perbedaan pada praktik buang air besar antara desa belum ODF (Kelurahan Jagir) dan desa ODF (Kelurahan Ketintang) dimana pada kepemilikan lahan pada Kelurahan Jagir masyarakat tidak memiliki lahan sendiri dan lahan yang ditempati merupakan milik PT. KAI yang berpengaruh pada ketersediaan jamban sehat, sekalipun memiliki jamban tetapi tidak dilengkapi dengan septic tank, sedangkan pada Kelurahan Ketintang rata-rata masyarakat memiliki lahan sendiri, sehingga mempermudah masyarakat memiliki jamban yang dilengkapi dengan septic tank.

Kesimpulan: Lahan yang ditempati masyarakat Jagir bukan milik sendiri sehingga mempersulit warga untuk membangun jamban sehat, serta jamban yang ada tidak memenuhi persyaratan jamban sehat, sedangkan masyarakat Ketintang yang rata-rata tinggal di dekat sungai tetapi telah menerapkan praktik buang air besar yang benar dengan menggunakan jamban sehat.
\end{abstract}

Kata Kunci : ODF, kepemilikan lahan, jamban sehat, jenis jamban, jarak rumah

\section{ABSTRACT}

Background: One of the efforts to improve health status in the environmental sector is the provision of a healthy physical environment such as a family toilet. Based on data from the 2019 National Cumulative Access to Sanitation Progress Report, the population of East Java who still uses healthy latrines is 879,969 households and those who have Open Defecation (OD) behavior are 969,663 families.

Objectives: Intervention of possible factors needs to be done because these factors are supporting/enabling factors, where if we do a certain intervention it will be difficult if the facilities and infrastructure are not available/ not supported.

Methods: This type of research is observational analytic quantitative and qualitative with a cross-sectional research design. The data analysis technique was univariately using the One-Sample Kolmogorov-Smirnov test and bivariate analysis using the Mann-Whitney U test. From this test, it is obtained that the test results are significant or significant $\alpha=0.05$, so there is a significant difference between the tested variables. The hypothesis is accepted if the $p$-value is $\leq 0.05$.

Results: The statistical test of the Mann Whitney $U$ test states that there is a difference in the practice of defecating between Kelurahan Jagir and Kelurahan Ketintang where land ownership in Kelurahan Jagir, the community does not own their land and the land occupied is owned by PT.KAI affects the availability of healthy 
latrines, even though it has a latrine but is not equipped with a septic tank, while in Ketintang Village the average person has their land, making it easier for the community to have a toilet equipped with a septic tank.

Conclusions: The land occupied by the Jagir community is not their own, making it difficult for residents to build healthy latrines, and the existing latrines do not meet the requirements for healthy latrines, while the Ketintang community who mostly live near the river but have implemented the correct practice of defecating using healthy latrines.

Keywords: $O D F$, land ownership, healthy latrine, type of latrine, house distance

\author{
*Koresponden : \\ santy.margaritha.dasi-2018@fkm.unair.ac.id \\ Santy Margaritha Dasi \\ ${ }^{1}$ Departemen Kesehatan Lingkungan, Fakultas Kesehatan Masyarakat, Universitas Airlangga, Kampus C \\ Mulyorejo, 60115, Surabaya, Jawa Timur, Indonesia
}

\title{
PENDAHULUAN
}

Lingkungan yang bersih merupakan dambaan semua orang, namun tidak mudah untuk bisa menciptakan lingkungan yang terlihat bersih dan rapi sehingga membuat nyaman. Menurut HAKLI (Himpunan Ahli Kesehatan Lingkungan Indonesia) Kesehatan Lingkungan adalah suatu kondisi lingkungan yang dapat menopang keseimbangan ekologi yang dinamis antara manusia dengan lingkungannya untuk mendukung tercapainya kualitas hidup manusia yang sehat dan bahagia. Sedangkan, menurut WHO Kesehatan Lingkungan adalah suatu keseimbangan ekologi yang harus tercipta diantara manusia dengan lingkungannya agar bisa menjamin keadaan sehat dari manusia.

Buang Air Besar Sembarangan (BABS) dapat menyebabkan pencemaran terhadap permukaan air tanah dan tanah sehingga berpotensi menjadi faktor penyebab timbulnya penularan penyakit saluran pencernaan. Penyakit yang dapat timbul antara lain hepatitis A, diare, kolera, disentri, infeksi gastrointestinal dan investasi parasit lain (Chandra, 2012). Menurut Peraturan Pemerintah Nomor 66 Tahun 2014 tentang Kesehatan Lingkungan menyatakan bahwa kesehatan lingkungan adalah upaya pencegahan penyakit dan/atau gangguan kesehatan dari faktor risiko lingkungan untuk mewujudkan kualitas lingkungan yang sehat baik dari aspek fisik, kimia, biologi, maupun sosial. Dalam penyelenggaraan kesehatan lingkungan maka pemerintah berwenang untuk menetapkan kebijakan dan strategi nasional penyelenggaraan kesehatan lingkungan salah satunya yaitu program STBM (Sanitasi Total Berbasis Masyarakat) yang bertujuan untuk meningkatkan mutu lingkungan hidup yang lebih sehat (PERMENKES, 2014).

Upaya peningkatan derajat kesehatan dalam sektor lingkungan salah satunya dapat dilakukan dengan pengadaan sarana lingkungan fisik yang sehat seperti jamban keluarga. Dengan ketersediaan akses jamban keluarga di setiap rumah, maka Open Defecation (OD) di Indonesia dapat ditekan. Menurut Abdullah (Abdullah, 2010), jamban adalah fasilitas pembuangan tinja manusia yang terdiri atas tempat jongkok maupun tempat duduk dengan leher angsa maupun tanpa leher angsa yang dilengkapi penampungan air dan kotoran untuk membersihkannya. Keputusan Menteri Kesehatan No. 852 Tahun 2008 tentang Strategi Nasional Sanitasi Total Berbasis Masyarakat, jamban sehat adalah fasilitas pembuangan kotoran manusia yang mana berisi semua zat yang tidak dipakai kembali oleh tubuh dan harus dikeluarkan. Jamaban sehat merupakan cara efektif untuk memutus mata rantai penularan. Berdasarkan data Laporan Kemajuan Akses Sanitasi Kumulatif Nasional Tahun 2019 dimana penduduk Indonesia yang telah memiliki Jamban Sehat Permanen (JSP) sebanyak 44.623.008 Kepala Keluarga (KK), yang memiliki akses Jamban Sehat Semi Permanen (JSSP) sebanyak 11.637.045 KK, yang masih menumpang jamban sehat sebanyak $5.660 .533 \mathrm{KK}$ dan yang masih melakukan perilaku Open Defecation (OD) sebanyak 8.953.719 KK.

Berdasarkan data Laporan Kemajuan Akses Sanitasi Kumulatif Nasional Tahun 2019, penduduk Jawa Timur yang telah memiliki akses JSP sebanyak 7.995.121 KK, akses JSSP sebanyak 1.764.795 KK, yang masih menumpang ke jamban sehat sebanyak 879.969 KK dan yang masih melakukan perilaku Open Defecation (OD) sebanyak 969.663 KK. Kota Surabaya dengan 27 kabupaten/kota yang ada di Jawa Timur juga belum mencapai Open Defecation Free (ODF). Kota Surabaya baru memiliki 7 kecamatan yang telah 100\% terverifikasi ODF dan tercatat masih ada 7 kecamatan yang belum terverifikasi ODF pada wilayah kelurahannya, yaitu Kecamatan Rungkut, Kecamatan Simokerto, Kecamatan Semampir, Kecamatan Pabean Cantian, Kecamatan Wonokromo,Kecamatan Asemrowo dan Kecamatan Gunung Anyar. Dan tidak mengalami peningkatan akses jamban sejak tahun 2017 (KEMENKES, 2019). 
Kecamatan Wonokromo merupakan salah satu wilayah yang terverifikasi desa ODF dengan pencapaian akses jamban terendah di wilayah Surabaya Selatan. Presentase sanitasi jambannya telah mencapai $97.68 \%$ namun masih ditemukan masyarakat yang Buang Air Besar Sembarangan (BABS) serta masyarakat yang belum memiliki septictank. Ada 6 kelurahan pada Kecamatan Wonokromo dan belum ada yang mendeklarasikan ODF. Kelurahan Jagir merupakan kelurahan dengan presentase jamban terendah dibandingkan kelurahan lainnya. Kelurahan Jagir memiliki wilayah pemukiman yang terletak di bantaran rel kereta api yang diketahui merupakan daerah pemukiman yang kumuh dan kurang peduli terhadap lingkungan.

Kecamatan Gayungan merupakan salah satu di wilayah Surabaya Selatan yang 4 (empat) kelurahannya sudah terverifikasi $100 \%$ ODF. Berdasarkan studi pendahuluan, Kelurahan Ketintang merupakan wilayah yang dilalui rel kereta api an memiliki pemukiman yang berada di bantaran rel kereta api. Dimana yang diketahui kawasan bantaran kereta api merupan tempat pemukiman penduduk dengan lingkungan yang kumuh, namun Kelurahan Ketintang dapat mengatasi hal tersebut dengan terbuktinya menjadi Kelurahan yang terverifikasi sebagai desa ODF. Menurut Natsir (NATSIR, 2016) pengelolaan sanitasi lingkungan dan perilaku hidup bersih perlu ada dukungan dari pelayanan sistem sanitasi yang terdiri dari pengelolaan sampah, saluran drainase, perilaku masyarakat dan kelembagaan sebagai kunci keberhasilan keberlanjutan lingkungan sehat, baik pada kawasan pedesaan, perkotaan dan juga wilayah urban.

Menurut Notoatmojo (Notoatmodjo, 2010) perilaku manusia adalah suatu refleksi dari berbagai kejiwaan seperti keinginan, minat, kehendak pengetahuan, emosi berpikir, sikap, motovasi dan reaksi. Dengan kata lain perilaku manusia merupakan aktivitas manusia yang berkaitan dengan pemeliharaan dan peningkatan kesehatan. Lawrence Green (2010) menyatakan perilaku seseorang dipengaruhi 3 faktor, yaitu : faktor predisposing, faktor enabling, dan faktor reinforcing. faktor enabling atau faktor pemungkin yang mengfasilitasi suatu perilaku atau tindakan. Faktor enabling merupakan faktor yang mencakup berbagai keterampilan dan sumber daya, dimana keterampilan dan sumber daya merupakan poin penting yang sangat diperlukan untuk melakukan perubahan perilaku kesehatan. Sumber daya itu seperti : Ketersediaan lahan, dimana pengadaan infrastruktur penyediaan jamban sehat dapat terhambat apabila tidak terdapat lahan untuk mendirikan jamban (Sukma, 2018). Sekalipun terdapat masyarakat dengan sikap positif terhadap program ODF namun mereka memiliki kendala dengan tidak tersedianya lahan yang luas untuk membangun jamban dan septic tank (Noviitry and Agustin, 2017).

Kepemilikan jamban sehat, dimana kepemilikan jamban sehat ini merupakan ada atau tidaknya sarana pembuangan tinja yang dimiliki oleh setiap rumah. Memiliki jamban di rumah menjadi faktor pemungkin seseorang dalam berperilaku sehat karena jamban memungkinkan setiap anggota keluarga untuk menggunakan jamban (Isral, 2017). Jenis jamban, dimana jenis jamban yang digunakan oleh masyarakat juga mempengaruhi masyarakat berperilaku sehat. Menurut penelitian Qudsiyah (Qudsiyah, Pujiati and Ningrum, 2015) didapati hasil bahwa rumah dengan jenis jamban leher angsa berpeluang lebih besar untuk digunakan jika dibandingkan dengan jenis jamban cemplung. Jarak rumah dengan sungai. Adanya hubungan yang signifikan antara jarak rumah dengan sungai dengan pemanfaatan jamban keluarga. Jarak rumah yang jauh dari sungai berpeluang 1.320 kali lebih besar dalam pemanfaatan jamban keluarga daripada rumah yang jaraknya dekat dengan sungai . hal ini didukung penelitian dari Qudisyah (Qudsiyah, Pujiati and Ningrum, 2015) yang menyatakan faktor yang menentukan masyarakat memanfaatkan air sungai karena secara geografis letak rumah penduduk yang berpinggiran langsung dengan sungai. Kebiasaaan penduduk yang secara turun temurun dengan sungai sebagai pilihan, dimana semakin dekat masyarakat dengan sungai maka semakin besar pemanfaatan air sungai untuk kebutuhan rumah tangga.

Tingkat pendapatan seseorang sangat dipengaruhi keputusan untuk menggunakan jamban karena penggunaan jamban bergantung pada ketersediaan sarana dan prasarana (Laika, 2019). Menurut Hapsari (Hapsari, 2016), ekonomi yang lemah merupakan permasalahan mendasar masyarakat belum memiliki jamban sehat secara pribadi. Kenapa kita perlu mengintervensi faktor enabling karena faktor ini merupakan faktor pendukung/pemungkin, dimana jika kita melakukan suatu interfensi tertentu akan sulit jika sarana dan prasarana tidak ada/ tidak mendukung. Perilaku seseorang atau masyarakat ditentukan oleh pengetahuan, sikap, kepercayaan, tradisi dan sebagainya. Namun jika hanya pengetahuan mengenai kesehatan saja tetapi tidak ada pra-sarananya, maka masyarakat tentunya tidak akan bisa menerapkan perilaku hidup bersih dan sehat. Hal inilah yang mengakibatkan mengapa kita perlu menginterfensi faktor enabling.

\section{METODE}

Penelitian yang digunakan adalah jenis penelitian observasional analitik kuantitatif dan kualitatif dengan desain penelitian potong lintang (Cross Sectional). Penelitian ini bersifat komparatif. Pengumpulan data primernya memalui wawancara dengan alat bantunya kuesioner dan data sekundernya berupa profil kelurahan, data STBM nasional, STBM Provinsi Jawa Timur, STBM Kota Surabaya, STBM kawasan Surabaya selatan, STBM Kecamatan Wonokromo, dan laporan Puskesmas Jagir terkait akses sanitasi tahun 2019. Teknik analisis data secara univariat yang bertujuan untuk mendeskripsikan karakteristik tiap variabel dan analisis bivariat dengan menggunakan uji Mann-Whitney $U$ test guna membandingkan dua variable atau lebih (Syarifudin,2010). Uji ini merupakan uji komparatif dua sampel independent apabila data yang disajikan dalam bentuk ordinal dan tidak normal atau tidak homogen. Dari uji ini diperoleh kemungkinan hasil uji yaitu signifikan atau bermakna 
$\alpha=0,05$ maka terdapat perbedaan yang bermakna antara variable yang diuji. Hipotesa diterima apabila $p$-value $\leq 0,05$. Populasi penelitian adalah seluruh masyarakat yang bertempat tinggal di wilayah bantaran rel kereta api yaitu Desa belum ODF (Kelurahan Jagir) yang berlokasi di RW 10 sebanyak 3 RT (RT 5, RT 6, dan RT 7) sejumlah 215 KK dan Desa ODF (Kelurahan Ketintang) di RW 3 sebanyak 2 RT (RT 6 dan RT 7) sejumlah 147 KK. Sampel dalam penelitian ini merupakan sebagain masyarakat yang diwakili oleh salah satu anggota keluarganya dengan usia minimal 17 tahun.

Besaran sampel untuk Desa belum ODF (Kelurahan Jagir) sebanyak 68 sampel dan Desa ODF (Kelurahan Ketintang) sebanyak 60 sampel. Pengambilan sampel menggunakan probability sampling dengan teknik sampling berupa proportional random sampling, yaitu pengambilan sampel secara proporsi dengan mengambil subjek dari setiap strata atau wilayah ditentukan seimbang dengan jumlah subjek dalam masing-masing strata atau wilayah. Perhitungan sampel permasing kelurahan sebagai berikut:

Variabel penelitian dengan komponen penilaiannya sebagai berikut: (1) Ketersedian lahan: Tersedia. Jika memiliki lahan untuk membangun jamban sehat di rumah atau tidak tersedia, jika tidak memiliki lahan untuk membangun jamban sehat di rumah. (2) Kepemilikan jamban sehat: Memiliki, jika memiliki jamban sehat di rumah atau tidak memiliki, jika tidak memiliki jamban sehat di rumah. (3) Jenis jamban : Selain di jamban, Jamban jongkok cemplung (tanpa septic tank), Jamban jongkok dengan septic tank, Jamban duduk dengan septic tank, Jamban umum. (4) Jarak rumah dengan sungai : Dekat (<100 meter), Sedang (100 meter -1000 meter), Jauh (>1000 meter)

\section{HASIL DAN PEMBAHASAN}

Tabel 1. Kepemilikan Lahan Responden di Kelurahan Jagir dan Kelurahan Ketintang, Kota Surabaya

\begin{tabular}{lrrrrr}
\hline Kepemilikan Lahan & \multicolumn{2}{c}{ Kel. Jagir (Desa Belum ODF) } & \multicolumn{2}{c}{ Kel. Ketintang (Desa ODF) } & \multirow{2}{*}{$\boldsymbol{p}$-value } \\
\cline { 2 - 5 } & $\mathbf{n}$ & $\boldsymbol{\%}$ & $\mathbf{n}$ & $\mathbf{\%}$ & \\
\hline Baik & 23 & 33,83 & 60 & 100,00 & $<0,001$ \\
Kurang & 45 & 66,17 & 0 & 0,00 & \\
\hline Total & 68 & 100,00 & 60 & 100,00 & \\
\hline
\end{tabular}

Sebagian responden di Kelurahan Jagir tidak memiliki lahan untuk membangun jamban sehat yaitu sebanyak 45 orang $(66,17 \%)$, sedangkan responden pada Kelurahan Ketintang seluruh masyarakat memiliki lahan sendiri $100 \%$. Hasil uji statistic Mann Whitney U test menyatakan bahwa terdapat perbedaan kepemilikan lahan terhadap praktik buang air besar antara desa belum ODF (Kelurahan Jagir) dengan desa ODF (Kelurahan Ketintang) dengan nilai $p$-value $<0,001,<\alpha=0,05$. Pembangunan jamban sehat memerlukan septic tank sebagai wadah menampung tinja yang mana septic tank memerlukan lahan khusus untuk pembangunannya. Keterbatasan lahan dapat meningkatkan peluang seseorang untuk tidak membangun jamban sehat di rumah (Mardotillah et al., 2019). Kepemilikan lahan sangat mempengaruhi warga untuk dapat membangun jamban sehat di rumah. Dengan memiliki lahan sendiri, seseorang dapat bebas membangun apa saja yang dibutuhkan termasuk pembangunan jamban sehat (Mardotillah et al., 2019). Kondisi rumah yang berada di desa belum ODF cenderung sempit yaitu dengan luas lahan sekitar $24 \mathrm{~m}^{2}$ hingga $36 \mathrm{~m}^{2}$. Selain itu, lahan yang menjadi pemukiman warga di RT 5, 6 dan 7 merupakan tanah milik PT Kereta Api Indonesia. Kondisi ekonomi yang kurang mendukung menjadikan masyarakat untuk mendahulukan pemenuhan kebutuhan pokok dibandingkan untuk membangun jamban sehat (Andini, 2017). Hasil penelitian ini didukung dengan penelitian yang dilakukan oleh Arlin, Sudirman dan Nur afni (Arlin, Sudirman and Nurafni, 2019), menunjukkan bahwa terdapat hubungan yang bermakna antara kepemilikan lahan dengan kepemilikan jamban sehat di Desa Ta,aniuge Kecamatan Tomini Kabupaten Parigi Moutong.

Tabel 2. Kepemilikan Jamban Sehat Responden di Kelurahan Jagir dan Kelurahan Ketintang, Kota Surabaya

\begin{tabular}{|c|c|c|c|c|c|}
\hline \multirow[t]{2}{*}{ Jamban Sehat } & \multicolumn{2}{|c|}{ Kel. Jagir (Desa Belum ODF) } & \multicolumn{2}{|c|}{ Kel. Ketintang (Desa ODF) } & \multirow{2}{*}{ p-value } \\
\hline & $\mathbf{n}$ & $\%$ & $\mathbf{n}$ & $\%$ & \\
\hline Baik & 23 & 33,83 & 60 & 100,00 & \multirow{2}{*}{$<0,001$} \\
\hline Kurang & 45 & 66,17 & 0 & 0,00 & \\
\hline Total & 68 & 100,00 & 60 & 100,00 & \\
\hline
\end{tabular}

Sebagian responden di kelurahan Jagir, tidak memiliki jamban sehat karena tidak memiliki lahan atau lahan yang ditempati bukan milik sendiri yaitu sebanyak 45 orang (66,17\%), sedangkan pada Kelurahan Ketintang semua masyarakat memiliki jamban sehat $100 \%$ hal ini dikarenakan masyarakat yang memiliki lahan sendiri. Hasil uji statistik Mann Whitney $U$ test yang menyatakan bahwa terdapat perbedaan kepemilikan jamban sehat terhadap praktik buang air besar antara desa belum ODF (Kelurahan Jagir) dengan desa ODF (Kelurahan Ketintang) dengan nilai $p$-value $<0,001,<\alpha=0,05$. Ketersediaan jamban di rumah berbanding lurus dengan perilaku keluarga dalam penggunaan jamban. Responden dengan jamban sehat di rumah memiliki peluang 300x 
lebih baik dalam penggunaan jamban ketika melakukan buang air besar jika dibandingkan dengan warga yang tidak memiliki jamban sehat (Anggoro, 2017). Permasalahan kepemilikan jamban sehat berasal dari ketidak tersedianya lahan yang ada untuk melakukan pembangunannya. Masyarakat yang tidak memiliki jamban sehat di desa belum ODF seluruhnya merupakan masyarakat dengan luas rumah yang relatif sempit sehingga tidak memungkinkan untuk membangun jamban sehat.

Tabel 3. Jenis Jamban yang Digunakan Responden di Kelurahan Jagir dan Kelurahan Ketintang, Kota Surabaya

\begin{tabular}{|c|c|c|c|c|c|}
\hline \multirow[t]{2}{*}{ Jenis Jamban } & \multicolumn{2}{|c|}{$\begin{array}{c}\text { Kel. Jagir (Desa Belum } \\
\text { ODF) }\end{array}$} & \multicolumn{2}{|c|}{ Kel. Ketintang (Desa ODF) } & \multirow[t]{2}{*}{$p$-value } \\
\hline & $\mathbf{n}$ & $\%$ & $\mathbf{n}$ & $\%$ & \\
\hline Selain Jamban & 0 & 0,00 & 0 & 0,00 & \\
\hline $\begin{array}{l}\text { Jamban jongkok cemplung } \\
\text { (tanpa septic tank) }\end{array}$ & 26 & 38,23 & 0 & 0,00 & \\
\hline $\begin{array}{l}\text { Jamban jongkok dengan } \\
\text { septic tank }\end{array}$ & 17 & 25,00 & 42 & 70,00 & $<0,001$ \\
\hline $\begin{array}{l}\text { Jamban duduk dengan } \\
\text { septic tank }\end{array}$ & 6 & 8,83 & 18 & 30,00 & \\
\hline Jamban umum & 19 & 27,94 & 0 & 0,00 & \\
\hline Total & 68 & 100,00 & 60 & 100,00 & \\
\hline
\end{tabular}

Sebagian responden di Kelurahan Jagir masih menggunakan jamban jongkok cemplung tanpa adanya septic tank. Hasil uji statistik Mann Whitney U test yang menyatakan bahwa terdapat perbedaan jenis jamban terhadap praktik buang air besar antara desa belum ODF (Kelurahan Jagir) dengan desa ODF (Kelurahan Ketintang) dengan nilai $p$-value $<0,001,<\alpha=0,05$. Kondisi lahan yang terbatas tidak memungkinkan untuk membangun septic tank. Pada Kelurahan Ketintang rata-rata responden telah menggunakan jamban jongkok dan jamban duduk yang telah dilengkapi dengan septic tank. Dibutuhkan lahan minimal seluas $4 \mathrm{~m}^{2}$ dengan ukuran ideal 1,5 x 1,5 x 2 meter untuk membangun septic tank ditambah dengan 1x1x2 meter untuk bahan resapannya (Suwastika and Dwipayani, 2010). Keterbatasan lahan ini kemudian menyebabkan masyarakat menyalurkan kotorannya untuk dibuang di tanah yang berada di bawah rumah atau disalurkan ke sungai terdekat.

Tabel 4. Jarak Rumah Responden Dengan Sungai di Kelurahan Jagir dan Kelurahan Ketintang, Kecamatan Wonokromo, Kota Surabaya

\begin{tabular}{lrrrrr}
\hline Jarak Rumah Dengan & \multirow{2}{*}{ Kel. Jagir (Desa Belum ODF) } & Kel. Ketintang (Desa ODF) & p-value \\
\cline { 2 - 6 } & $\mathrm{n}$ & $\%$ & $\mathrm{n}$ & $\%$ & \\
\hline Dekat & 46 & 67,64 & 60 & 100,00 & \\
Sedang & 22 & 32,36 & 0 & 0,00 & $<0,001$ \\
Jauh & 0 & 0,00 & 0 & 0,00 & \\
\hline Total & 68 & 100 & 60 & 100,00 \\
\hline
\end{tabular}

Sebagian besar rumah responden di Kelurahan Jagir memiliki jarak rumah yang dekat dengan sungai ( $<100$ meter), Hal ini menyebabkan masyarakat cenderung membuang tinja di sungai. Pada Kelurahan Ketintang hampir semua masyarakat memiliki jarak rumah yang dekat dengan sungai ( $<100$ meter). Hasil uji statistik Mann Whitney $U$ test yang menyatakan bahwa terdapat perbedaan jarak rumah dengan sungai terhadap praktik buang air besar antara desa belum ODF (Kelurahan Jagir) dengan desa ODF (Kelurahan Ketintang) dengan nilai $p$ value $<0,001,<\alpha=0,05$.

Jarak rumah dengan sungai adalah salah satu faktor penguat yang mengakibatkan seseorang melakukan buang air besar sembarangan, utamanya jarak dengan sungai. Faktor ini menjadikan seseorang merasa bahwa kepemilikan jamban sehat di rumah menjadi faktor tidak penting karena beranggapan kotoran dari jamban dapat disalurkan ke sungai. Penelitian oleh Soleh (Soleh, 2002) menyatakan bahwa terdapat hubungan antara jarak rumah dengan sungai dengan pemanfaatan jamban keluarga, dan ini diperkuat dengan penelitian dari Kurniawati,dkk (Kurniawati, 2015) dimana masyarakat pemukiman kampung nelayan tambak lorok tidak memiliki jamban pribadi dan kotoran langsung dibuang ke laut tanpa menggunakan saptic tank.

Demikian juga menurut Sukma (Sukma, 2018) dimana $59.7 \%$ masyarakat masih membuang langsung tinja dari jamban ke sungai. Masyarakat yang jarak rumahnya jauh dengan sungai memiliki peluang sebesar 1,320x lebih besar dalam pemanfaatan jamban keluarga daripada masyarakat yang memiliki rumah dekat dengan sungai. Hal tersebut tidak sejalan dengan penelitian ini yang mana menunjukkan bahwa rumah di desa ODF seluruhnya memiliki jarak rumah yang dekat ( $<100$ meter) dengan sungai sedangkan di desa belum ODF terdapat beberapa rumah masyarakatnya yang berjarak sedang $(100-1000$ meter). Suwastika(Suwastika and Dwipayani, 2010) dalam penelitianya di Dangin Puri, Denpasar dimana jarak jamban kurang dari 10 meter 
berpotensi 8,733 kali untuk mengalirkan limbah tinja ke sungai dibandingkan dengan KK dengan jarak jamban lebih dari 10 meter dari sungai.

\section{KESIMPULAN}

Responden di Kelurahan Jagir tidak memiliki lahan serta jamban sehat di rumah. Dimana lahan yang ditempati merupakan milik PT. Kereta Api Indonesia. Hal tersebut menjadikan masyarakat di wilayah ini memiliki praktik buang air besar yang buruk dimana sebagian besar masyarakat masih membuang tinja di sungai, sekalipun memiliki jamban jongkok cemplung tapi tidak ada septic tank dan menggunakan fasilitas umum berupa jamban umum. Sedangkan, Kelurahan Ketintang ini dilewati beberapa aliran anak sungai dan perlintasan rel kereta api, meskipun begitu, masyarakat di wilayah ini telah memiliki jamban sehat dan melakukan praktik buang air besar dengan baik.

\section{ACKNOWLEDGMENT}

Terima kasih penulis sampaikan kepada BANGKESDAPOL Surabaya, Kepala Dinas Kesehatan Kota Surabaya, Camat Wonokromo, Camat Gayungan, Lurah Jagir, dan Lurah Ketintang yang telah memberikan ijin untuk melaksanakan penelitian ini sehingga penelitian ini dapat berjalan dengan lancar.

\section{REFERENSI}

Abdullah (2010) 'Tujuh Syarat Membangun Jamban Sehat', 2010. Available at: https://www.sanitasi.or.id/index.php?option=com.

Andini, S. A. (2017) 'Analisis Faktor Yang Berhubungan Dengan Perilaku Orangtua Tentang Open Defecation Pada Anak Usia Sekolah Berdasarkan Teori Transkultural Nursing'. Available at: http://repository.unair.ac.id/id/eprint/69593.

Anggoro, R. R. (2017) 'Gambaran Perilaku Buang Air Besar Sembarangan Pada Masyarakat Desa Jatimulyo, Kabupaten Bojonegoro', Universitas Nusantara PGRI Kediri, 01(2), pp. 1-7. Available at: http://www.albayan.ae.

Arlin, Sudirman and Nurafni (2019) 'Faktor Yang Berhubungan dengan Kepemilikan Jamban di Desa Ta'aniuge Kecamatan Tomini Kabupaten Parigi Moutong', Journal of Chemical Information and Modeling, 53(9), pp. $1689-1699$.

Chandra, B. (2012) Pengantar Kesehatan Lingkungan. Penerbit B.

Hapsari, V. N. (2016) Faktor Yang Mempengaruhi Peran Serta Masyarakat Dalam Pelaksanaan Program Open Defecation Free (ODF) (Studi Kasus Di Kelurahan Karanganyar Kota Pasuruan). Airlangga.

Isral, F. (2017) 'Faktor-Faktor Yang Berhubungan Dengan Kepemilikan Jamban Keluarga Di Jorong Ranah Kecamatan Pulau Punjung Kabupaten Dharmasraya Tahun 2017'.

KEMENKES (2019) 'STBM (Sanitasi Total Berbasis Masyarakat). [Online] Available at: http://www.monev.stbm.kemkes.go.id/'. Available at: http://www.monev.stbm.kemkes.go.id/ [Accesed Selasa, 6 Oktober 2020].

Kurniawati, L. D. (2015) 'BERPENGARUH, FAKTOR - FAKTOR YANG KELUARGA, TERHADAP PERILAKU KEPALA PEMUKIMAN, DALAM PEMANFAATAN JAMBAN DI LOROK, KAMPUNG NELAYAN TAMBAK SEMARANG'.

Laika, A. (2019) Hubungan Faktor Predisposisi, Faktor Penguat, Faktor Pendorong Dan Kepemilikan Jamban Terhadap Rendahnya Penggunaan Jamban Di RW. 01 Kelurahan Gunung Anyar Tambak KotaSurabaya. Airlangga.

Mardotillah, M. et al. (2019) 'Peran Faktor Pemungkin Dan Penguat Pada Akses Jamban Sehat Perkotaan', Jurnal Antropologi: Isu-Isu Sosial Budaya, 20(2), p. 165. doi: 10.25077/jantro.v20.n2.p165-178.2018.

NATSIR, S. (2016) 'Rencana Pengelolaan Sanitasi Lingkungan Di Sekitar Aliran Sungai Mangolo Kabupaten Kolaka'.

Notoatmodjo, S. (2010) Promosi Kesehatan Teori dan Aplikasi. Jakarta: Rineka Cipta.

Noviitry, F. and Agustin, R. (2017) 'Determinan Kepemilikan Jamban Sehat Di Desa Sukomulyo Martapura Palembang', (2 (2)), pp. 107-116.

PERMENKES (2014) Peraturan Menteri Kesehatan No 3 Tahun 2014 Tentang Sanitasi Total Berbasis Masyarakat. Jakarta: Kemenkes RI.

Qudsiyah, W. A., Pujiati, R. S. and Ningrum, P. T. (2015) 'Faktor-faktor yang berhubungan dengan Tingginya angka open defecation (OD) di kabupaten Jember (studi di desa Sumber Kalong kecamatan Kalisat)', $e$ Jurnal Pustaka Kesehatan, 3(2), pp. 362-369. Available at: https://jurnal.unej.ac.id/index.php/JPK/article/view/2679.

Samosir, K. and Ramadhan, F. S. (2019) 'Peranan Perilaku dan Dukungan Tokoh Masyarakat terhadap Kepemilikan Jamban Sehat di Tanjungpinang', Jurnal Kesehatan, 0(1), pp. 77-86. Available at: 
http://journals.ums.ac.id/index.php/JK/article/view/7668/pdf.

Sukma, H. (2018) 'Hubungan Pengetahuan, Sikap Bab, Dan Kepemilikan Septic tank Dengan Status Odf (Open Defecation Free) Di Kecamatan Candisari Kota Semarang', Jurnal Kesehatan Masyarakat (e-Journal), 6(6), pp. 143-149.

Suwastika, D. G. and Dwipayani, N. M. U. (2010) 'Faktor-Faktor yang Mempengaruhi Ketersediaan Septictank dan Pemanfaatan Sarana Sewerage System Pada Masyarakat Pinggiran Kali Di Kelurahan Dangin Puri Kecamatan Denpasar Timur', Kongres Nasional Ikatan Ahli Kesehatan Masyarakat Indonesia, (September).

Ulina, Y. I., Darmana, A. and Aini, N. (2019) 'Faktor-faktor yang mempengaruhi masyarakat tidak memanfaatkan jamban di Desa Aek Kota Batu', 01(1), pp. 40-48.

Wirawan, P., Razak, A. and Dewata, I. (2017) 'Relationship Education, Income, Knowledge and Public Attitudes With Utilization of Communal Mck', PROMOTIF: Jurnal Kesehatan Masyarakat, 7(2), p. 136. doi: 10.31934/promotif.v7i2.87. 